\title{
螺旋藻耐盐相关基因启动子区功能分析
}

李姗姗 $^{1}$, 雍静茹 ${ }^{1}$, 齐云玲 ${ }^{1}$, 章颖 ${ }^{1}$, 赵亮 ${ }^{1}$, 夏士林 ${ }^{1}$, 李东 ${ }^{2}$, 王慧利 ${ }^{1}$, 包其郁 ${ }^{1}$, 李佩珍 ${ }^{2}$

1. 温州医学院检验医学与生命科学学院, 温州 325000 ;

2. 温州医学院生物学实验教学中心, 温州 325000

摘要：文章利用绿色荧光蛋白基因作为报告基因，研究 2 个螺旋藻耐盐相关基因启动子区域的功能。通过启动 子预测软件预测螺旋藻耐盐相关基因 $5^{\prime}$ 端非翻译区的启动子结构, 用Primer3.0 程序在线设计引物, 以 载体和pUC18 载体克隆螺旋藻启动子序列、 $g f p$ 和卡那霉素抗性基因, 将螺旋藻启动子-GFP基因-卡那霉素抗性 基因(pro-gfp-kan ${ }^{\mathrm{r}}$ )三联DNA片段克隆至pKW1188 载体, 并将该重组质粒pKW1188::pro::gfp::kan ${ }^{\mathrm{r}}$ 转化至受体菌 集胞藻 6803, 激光共聚焦显微镜观察不同盐浓度培养条件下、不同时间段集胞藻表达GFP的情况。结果显示, 通 过不同盐浓度和不同时间的诱导, 2 个螺旋藻启动子在 $0.4 \sim 0.6 \mathrm{~mol} / \mathrm{L} \mathrm{NaCl}$ 条件下, 培养 $6 \sim 8 \mathrm{~h}$ 表达的绿色荧光蛋 白最多。文章成功构建了以绿色荧光蛋白为报告基因、卡那霉素抗性基因为选择标记、集胞藻 6803 作为外源 基因表达受体, 进行螺旋藻耐盐相关基因功能研究的平台; 另外, 从螺旋藻启动子能被盐诱导大量表达GFP的 结果看, 与启动子相关的螺旋藻基因很可能与螺旋藻的耐盐性相关。

关键词：绿色荧光蛋白; 螺旋藻; 启动子; 集胞藻; 耐盐相关基因

\section{Functional analysis of promoter fragments of salt-tolerance related genes in Spirulina}

LI Shan-Shan ${ }^{1}$, YONG Jing-Ru ${ }^{1}$, QI Yun-Ling ${ }^{1}$, ZHANG Ying ${ }^{1}$, ZHAO Liang ${ }^{1}$, XIA Shi-Lin ${ }^{1}$, LI Dong ${ }^{2}$, WANG Hui-Li ${ }^{1}$, BAO Qi-Yu ${ }^{1}$, LI Pei-Zhen ${ }^{2}$

1. School of Labtory and Life Science, Wenzhou Medical College, Wenzhou 325000, China;

2. Biological Experiment Teaching Center of Wenzhou Medical College, Wenzhou 325000, China

\begin{abstract}
In this work, the functions of promoter fragments of two potential salt-tolerance related genes of Spirulina (Spirulina platensis Geitl.) were studied using green fluorescent protein gene ( $g f p$ ) as a reporter. The promoter structures of two salt-tolerance related genes of Spirulina were predicted using online promoter prediction software. pMD18-T and pUC18 vectors were used to clone the promoter sequences as well as the $g f p$ gene and kanamycine resistance (kan) gene. The fragments containing pro-gfp- kan $^{\mathrm{r}}$ were further cloned into $\mathrm{pKW} 1188$ vector and the resulting recombinant plasmids were then transformed into a host strain Synechocystis sp. (Synechocystis pevalekii Ercegovic) PCC6803. The resulting bacterial strains were grown under various concentrations of salinity for defining time intervals. The bacterial fluorescence was ob-
\end{abstract}

收稿日期: 2011-03-28; 修回日期: 2011-05-11

基金项目: 国家自然科学基金项目(编号: 30571009,31071115)和浙江省科技计划项目(编号：2009C33040)资助

作者简介: 李姗姗，在读本科，专业方向：临床检验诊断学。E-mail: 403855797@qq.com

通讯作者: 李佩珍, 硕士, 实验师, 研究方向 : 分子生物学。E-mail: 1pz0522@126.com

网络出版时间: 2011-8-22 10:05:00

URL: http://www.cnki.net/kcms/detail/11.1913.R.20110822.1005.004.html 
served using laser confocal microscope. Our results showed that the transgenic bacteria grown at different concentrations of salinity for various periods produced varying fluorescence intensities. The bacteria treated with $\mathrm{NaCl}$ at the concentrations of $0.4 \mathrm{~mol} / \mathrm{L}$ to $0.6 \mathrm{~mol} / \mathrm{L}$ for 6 to $8 \mathrm{~h}$ showed the strongest fluorescent intensity. From the result of high salt induced expression of $g f p$, we predicted that the genes under control of these two promoters are likely to play important roles in the salt tolerance of Spirulina. Accordingly, we believed that a research platform for the studying functions of the promoters of the salt-tolerance related genes in Spirulina has been developed with the $g f p$ as a reporter, the kan $^{\mathrm{r}}$ gene as the selection marker, and Synechocystis. sp. PCC6803 as the expression host.

Keywords: green fluorescent protein; Spirulina; promoter; Synechocystis.sp.PCC6803; salt-tolerance related gene

螺旋藻(Spirulina) 属于蓝藻门(Cyanophyta)、蓝 藻纲(Cyanophyceae)、颤藻目(Orcillatoriales)、颤藻 科 (Oscillatoniaceae) 、螺旋藻属 (Spirulina 或 Arthrospira), 是一类进化历史悠久、革兰氏染色阴 性、无鞭毛、含叶绿素 $\mathrm{a}$ (但不形成叶绿体)、能进行 产氧性光合作用的大型原核生物，广泛分布于自然 界的陆地、淡水域和海洋中, 甚至在岩石表面也能 发现它们的踪迹。螺旋藻能够耐受强光、强碱和高 盐等极端条件, 其最适钠离子浓度为 150 200 $\mathrm{mmol} / \mathrm{L}$, 可耐 $1 \mathrm{~mol} / \mathrm{L}$ 的 $\mathrm{NaCl}{ }^{[1,2]}$ 。极强的耐盐能力、 简单的细胞结构以及便利的培养条件使人们对螺旋 藻的耐盐机理产生了浓厚兴趣, Wiangnon等 ${ }^{[3]}$ 发现 Aphanothece halophytica 包膜存在钠诱导型ATP酶 与蓝细菌的耐碱性有关, 方孝东等 ${ }^{[4 ~ 6]}$ 认为盐藻在 受到高渗刺激时, 转铁蛋白和碳酸脱水酶基因表达 增强。虽然国内外都开展了对蓝细菌抗盐碱等抗逆 性机制的研究，但迄今还没有学者从基因组、蛋白 组水平比较系统地研究螺旋藻抗盐碱分子机理。前 期研究中, 在本课题组完成的螺旋藻全基因组序列 图的基础上, 采用蛋白组学方法分离和鉴定了螺旋 藻耐盐胁迫反应相关蛋白, 并通过质谱分析篲选出 螺旋藻在受到盐胁迫时差异表达最明显的 2 个基因 (本课题组未发表数据)。为进一步验证这 2 个基因的 功能, 本研究中我们选择遗传背景清楚便于进行基 因序列和功能分析的集胞藻 6803 作为外源基因表 达受体, 其全基因序列已经于 1996 公布 ${ }^{[7]}$, 以 $g f p$ 为 报告基因，构建相应的集胞藻 6803 同源重组双交换 整合平台, 开展启动子表达调控研究。通过分析不 同的启动子在集胞藻 6803 的相对转录起始效率, 为 篮选高效表达启动子提供参考依据，为拓建耐盐基 因资源库，揭示耐盐分子机制，以及耐盐植物的分
子育种等进一步研究奠定基础。

\section{1 材料和方法}

\section{1 材料}

pMD18- $\mathrm{T}$ 质粒、基因重组各种工具酶购自宝生 物工程(大连)有限公司, $\mathrm{pUC} 、 \mathrm{pET}-28 \mathrm{a}$ 质粒为本实 验室保存, pKW1188 质粒为本校王慧利老师惠赠, 螺旋藻、大肠杆菌 JM109 为本实验室保存, 含 GFP 基因的细菌为浙江大学吴敏教授惠赠, 集胞藻购自 中科院武汉水生所, PCR 纯化试剂盒、琼脂糖凝胶回 收试剂盒、质粒纯化试剂盒为艾思进公司产品，引 物合成由上海捷瑞公司完成，激光共聚焦显微镜 FV1000 购自日本 Olympus 公司, 苂光分光光度计 RF-5301PC 购自日本 Shimaszu 公司。

\section{2 方法}

\subsection{1 引物设计}

根据螺旋藻耐盐性蛋白组研究结果, 篮选出 2 个在高盐 $(1 \mathrm{~mol} / \mathrm{L}$ )环境下明显上调的螺旋藻基因(分 别命名为 spi-049、spi-295)。根据螺旋藻基因组序列 的注释结果，找到这 2 个基因的对应基因组序列， 再用 online promoter system 预测基因上游序列中的 启动子序列, 用在线引物软件 primer3.0 设计 2 对扩 增启动子片段引物, 扩增片段长度为 200 和 $250 \mathrm{bp}$, 分别在各启动子引物上游 5 端加入 $X b a$ I 的酶切位 点, 引物下游加入绿色菼光蛋白(GFP)基因 5'端部分 序列(表 1); 在 GFP 基因的上游引物 5'端加入启动子 3'端的部分序列, 在 GFP 基因的下游引物 3'端加入 Bam H I 的酶切位点(表 1)。在卡那霉素抗性基因引 物的上下游分别加 Bam H I 和 Hind III 酶切位点。 
表 1 螺旋藻启动子区、绿色苂光蛋白基因和卡那霉素抗性基因的引物

\begin{tabular}{|c|c|c|}
\hline 引物 * & 序列 $\left(5^{\prime} \rightarrow 3^{\prime}\right)$ & 长度(bp) \\
\hline \multirow{2}{*}{ pro-spi-049 } & F1 : GTCTAGAGATTGATCGGTGTTGACAGACCG & \multirow{2}{*}{200} \\
\hline & R1: AGTTCTTCTCCTTTACTCATTGGGATTGTCAGAACTCTGTTGA & \\
\hline \multirow{2}{*}{ pro-spi-295 } & F1: GTCTAGACTTCGGGCGCTCGCTTCTTTAAA & \multirow{2}{*}{250} \\
\hline & R1: AGTTCTTCTCCTTTACTCATGAAAATCAGAATTGAATGGTCTAA & \\
\hline \multirow{2}{*}{ gfp-049 } & F2: ACAGAGTTCTGACAATCCCAATGAGTAAAGGAGAAGAACTTTTCAC & \multirow{2}{*}{718} \\
\hline & R2 : GGGATCCTTATTTGTATAGTTCATCCATGCCA & \\
\hline \multirow{2}{*}{ gfp-295 } & F2 : ACCATTCAATTCTGATTTTCATGAGTAAAGGAGAAGAACTTTTCAC & \multirow{2}{*}{718} \\
\hline & R2: GGGATCCTTATTTGTATAGTTCATCCATGCCA & \\
\hline \multirow{2}{*}{$\mathrm{kan}^{\mathrm{r}}$} & F3 : AGGATCCTTTGATCTTTTCTA & \multirow{2}{*}{800} \\
\hline & R3 : TAAGCTTAGAAAAACTCATCGAGCATC & \\
\hline
\end{tabular}

注： * pro-spi-049:螺旋藻预测启动子 049 的重组 PCR 引物; gfp-049: 绿色荧光蛋与螺旋藻预测启动子 049 重组 PCR 的引物。

\subsection{2 螺旋藻、集胞藻总 DNA 的提取}

螺旋藻总DNA提取采用液氮研磨法 ${ }^{[8]}$ 。集胞藻 PCC6803 总DNA按徐旭东等(1993) $)^{[9]}$ 描述的方法 提 取。

1.2.3 启动子序列、GFP 基因和卡那霉素抗性基因 的扩增

启动子序列的 PCR 扩增: 以螺旋藻基因组 DNA 为模板, 利用上述表 1 的 2 对引物(各启动子的 F1 和 R1)分别扩增相应的启动子序列, 条件为: $94^{\circ} \mathrm{C}$ 预 变性 $5 \mathrm{~min}, 94^{\circ} \mathrm{C}$ 变性 $40 \mathrm{~s}, 60^{\circ} \mathrm{C}$ 复性 $30 \mathrm{~s}, 72^{\circ} \mathrm{C}$ 延伸 $40 \mathrm{~s}$, 共 35 个循环, $72^{\circ} \mathrm{C}$ 延伸 $10 \mathrm{~min}$ 。 $\mathrm{PCR}$ 产物在琼 脂糖凝胶上电泳检测, 切下所需目的条带试剂盒回 收后备用。

GFP 基因的 PCR 扩增：以含 GFP 基因的单菌 落为模板, 利用上述表 1 的 2 对引物(各启动子对应 的 F2 和 R2)分别扩增 GFP 的开放阅读框, 条件为: $94^{\circ} \mathrm{C}$ 预变性 $5 \mathrm{~min}, 94^{\circ} \mathrm{C}$ 变性 $40 \mathrm{~s}, 55^{\circ} \mathrm{C}$ 复性 $30 \mathrm{~s}, 72$ ${ }^{\circ} \mathrm{C}$ 延伸 $40 \mathrm{~s}$, 共 35 个循环, $72^{\circ} \mathrm{C}$ 延伸 $10 \mathrm{~min}$ 。 $\mathrm{PCR}$ 产物在琼脂糖凝胶上电泳检测, 切下所需目的条带 试剂盒回收后备用。

重组 PCR 获得启动子序列与 GFP 基因重组片段 pro-gfp : 以启动子和 GFP 基因 PCR 扩增产物为模板, 利用 2 对引物(表 1 中的各启动子对应的 F1 和 R2 引 物)进行重组 PCR 扩增, 条件为: $94^{\circ} \mathrm{C}$ 预变性 $5 \mathrm{~min}$, $94^{\circ} \mathrm{C}$ 变性 $40 \mathrm{~s}, 55^{\circ} \mathrm{C}$ 复性 $30 \mathrm{~s}, 72^{\circ} \mathrm{C}$ 延伸 $40 \mathrm{~s}$, 共 35 个循环, $72^{\circ} \mathrm{C}$ 延伸 $10 \mathrm{~min}$ 。PCR 产物在琼脂糖凝胶上 电泳检测，切下所需目的条带试剂盒回收后备用。

卡那霉素抗性基因的PCR扩增：以含卡那霉素
抗性基因的pET-28a质粒为模板，利用卡那霉素抗 性基因引物进行PCR扩增 $k a n^{\mathrm{r}}$ 的开放阅读框，条件 为: $94^{\circ} \mathrm{C}$ 预变性 $5 \mathrm{~min}, 94^{\circ} \mathrm{C}$ 变性 $40 \mathrm{~s}, 55^{\circ} \mathrm{C}$ 复性 $30 \mathrm{~s}$, $72^{\circ} \mathrm{C}$ 延伸 $40 \mathrm{~s}$, 共 35 个循环, $72^{\circ} \mathrm{C}$ 延伸 $10 \mathrm{~min}$ 。 $\mathrm{PCR}$ 产物在琼脂糖凝胶中电泳检测, 切下所需目的条带 试剂盒回收后备用。

\subsubsection{PCR 产物的克隆与测序验证}

将启动子序列与 GFP基因的重组PCR产物以及 卡那霉素抗性基因片段分别与 $\mathrm{pMD} 18-\mathrm{T}$ 载体连接, $16^{\circ} \mathrm{C}$ 过夜, 反应产物转化入感受态大肠杆菌JM109, 在含氨苄青霉素平板上通过蓝白斑结合菌落PCR篮 选获得阳性克隆(pMD18-pro::gfp和pMD18-kan ${ }^{\mathrm{r}}$ 重组 子), 提取质粒经双酶切鉴定后送生物公司测序。

\subsection{5 构建pUC-pro::gfp:: kan ${ }^{\mathrm{r}}$ 重组子}

根据各自的酶切位点, 用 Xba | 和 BamH I 双酶 切下 pMD18-pro::gfp上的pro::gfp 片段, 用 BamH I 和Hind III 双酶切下pMD18-kan ${ }^{\mathrm{r}}$ 上的卡那霉素抗性基 因。同时, 用Xba | 和Hind III 双酶切 $\mathrm{pUC} 18$ 载体。 将其连接, 构建 $\mathrm{pUC}$-pro::gfp:: $k a n^{\mathrm{r}}$ 重组子, $16^{\circ} \mathrm{C}$ 过夜, 反应产物转化入JM109(感受态), 通过蓝白斑篮选获 得阳性克隆，并提取质粒双酶切鉴定。

\subsection{6 构建pKW-pro::gfp:: kan ${ }^{\mathrm{r}}$ 重组子}

用EcoR I 将pKW1188 质粒进行酶切, 然后补 平末端, 去磷酸化。同时, 用 Xba I 和Hind III 从 pUC-pro::gfp:: kan ${ }^{\mathrm{r}}$ 重组质粒中切下pro::gfp:: $k a n^{\mathrm{r}}{ }^{\mathrm{J}}$ 片 段, 末端补平后, 将其与末端补平去磷酸化的 pKW1188 载体链接, 构建 $\mathrm{pKW}-\mathrm{pro}:: g f p:: k a{ }^{\mathrm{r}}$ 重组 
质粒, 经卡那霉素抗性篮选获得阳性克隆, 提取质 粒PCR鉴定。将经过抗性篮选和PCR鉴定的菌落扩 大培养，提取重组质粒备用。

\subsection{7 集胞藻的自然转化}

根据文献报道, 利用自然转化法 ${ }^{[9]}$ 进行, 具体 步骤如下: 将混合纤维酯膜以蒸馏水浸泡 3 次, 每 次 $5 \mathrm{~min}$; 煮沸 $3 \mathrm{~min}$, 之后置玻璃培养血中灭菌待 用, 初始接种浓度的 $O D_{730}$ 约为 0.2 , 生长 $2 \mathrm{~d}$ 左右 使藻的光密度 $\left(O D_{730}\right)$ 为 $0.5 \sim 1.0$ 时, 取 $10 \mathrm{~mL}$ 的藻 液, 离心 (6 $000 \mathrm{r} / \mathrm{min}, 5 \mathrm{~min})$, 用新鲜BG-11 洗涤一 次并重悬于BG-11 中, 取 $0.1 \mathrm{~mL}$ 细胞悬液与相应的 重组质粒pKW-pro::gfp::kan ${ }^{\mathrm{r}}$ 在 $30^{\circ} \mathrm{C}$ 混匀, 在光照下 温育 $4 \mathrm{~h}$ 后涂于覆有混合纤维酯膜的BG-11 平板。光 照培养 $1 \mathrm{~d}$ 后, 将膜转到含 $10 \mu \mathrm{g} / \mathrm{mL}$ 卡那霉素的平板 上, 并给予不同的高渗环境继续光照培养, 野生藻 在抗生素篮选压力下逐渐死亡，7 10 d后在滤膜上 会长出转基因藻的单克隆。

\subsection{8 转化子检测 $[10]$}

利用 PCR 扩增检测。集胞藻通气培养至对数生 长期, 然后提取染色体 DNA。以染色体 DNA 作为 模板、 $g f p$ 对应引物作为引物, 进行 PCR 扩增试验。 发生了同源重组交换的转基因藻染色体上含有目的基 因, 因此可以扩增出 $g f p$ 对应大小的 DNA 片段条带。

\subsection{9 荧光检测}

用 $40 \mu \mathrm{L}$ 生理盐水洗下混合纤维酯膜上的转基 因藻，混合后滴加到载玻片上，用盖玻片压薄成标 本片。将制好的标本片先用光学显微镜观察, 再用 激光共聚焦显微镜，在 $488 \mathrm{~nm}$ 的激发波长下观察。 以野生集胞藻 6803 作为对照扣除背景, 观察有转化子 的集胞藻 6803 的绿色苂光，同时拍照记录保存图片。

\subsubsection{0 不同盐浓度下 GFP 的诱导表达}

取 $250 \mathrm{~mL}$ 起始浓度为 $O D_{730}=0.6 \sim 1.0$ 的转基因 集胞藻, 分装成 12 份, 每份 $20 \mathrm{~mL}$, 分成两组, 每组 6 份。在各组不同管中依次加入 $\mathrm{NaCl}$ 溶液, 使终浓度 分别为 $0.0 、 0.2 、 0.4 、 0.6 、 0.8 、 1.0 \mathrm{~mol} / \mathrm{L}$ 。再各取 $3 \mathrm{~mL}$ 相同藻浓度未经转化的集胞藻 6803 作为对照 组。将 3 组都放在 $30^{\circ} \mathrm{C}$ 持续光照的环境下培养 $12 \mathrm{~h}$, 以加入盐的那一刻开始计时，在 $0 h 、 2 h 、 4 h 、 6 h$ 、 $8 \mathrm{~h} 、 10 \mathrm{~h} 、 12 \mathrm{~h}$ 共 7 个时间点分别对转基因集胞藻
进行取样制标本片, 通过激光共聚焦显微镜直接活 体观察绿色苂光强度并拍照。再取各条件下的 $2 \mathrm{~mL}$ 转基因藻置于超声波细胞破碎仪破碎细胞壁，使用 菼光分光光度计进行定量分析。重复 3 次取平均值, 统计学分析使用SPSS 17.0 软件。

\section{2 结果与分析}

\section{1 螺旋藻耐盐相关基因启动子序列的预测}

根据螺旋藻在不同盐浓度下蛋白组分析结果, 选取 2 个在高盐浓度下高度表达的螺旋藻基因为研 究对象。应用在线 promoter system(http://www. softberry.ru/berry.phtml)对 2 个基因的 5端非翻译区 的 $300 \mathrm{bp}$ 范围内进行启动子序列分析, 结果表明在 2 个基因(spi049、295)的 5'端非翻译区内都预测到类 似于 TATA-box、CAAT-box 和多个富含 GC 的区域 等启动子的特征元件(图 1)。在 2 个基因的 5 端非翻 译区 200 300 bp 设计 PCR 引物, 进行 PCR 扩增。

\section{2 载体pKW-pro::gfp:: $\mathrm{kan}^{\mathrm{r}}$ 的构建及转化子检测}

以螺旋藻耐盐相关基因启动子(pro)的PCR产物 和 $g f p$ 为模板, 用螺旋藻耐盐相关基因启动子的上游 引物和 GFP基因下游引物进行重组PCR扩增, 结果 得到片段大小约为 $1000 \mathrm{bp}$ 的条带(pro::gfp, 启动子 和GFP基因序列的总和)，与预期的结果相符。将重 组PCR产物及卡那霉素抗性基因PCR产物分别克隆 至pMD18-T载体，经测序鉴定正确后，再将两者各 自双酶切后, 将目的片段一并克隆至pUC18 载体, 得到pUC-pro::gfp::kan ${ }^{\mathrm{r}}$ 。pUC-pro::gfp::kan ${ }^{\mathrm{r}}$ 重组质粒 用Xba | 和Hind III双酶切后, 可见约 $2.7 \mathrm{~kb}$ 和 $1.8 \mathrm{~kb}$ 大小的条带, 回收 pro::gfp::kan ${ }^{\mathrm{r}}$ 片段, 克隆至 $\mathrm{pKW} 1188$ 载体, 转化后在含卡那霉素平板上篮选含 重组子 pKW-pro::gfp::kan ${ }^{\mathrm{r}}$ 菌株，提取质粒进行 PCR 鉴定，最后得到含螺旋藻spi-049、spi-295 基因启动 子的重组质粒pKW-pro::gfp::kan ${ }^{\mathrm{r}}$ 。

转基因藻染色体 DNA 经 PCR 扩增出现一特异 性条带, 大小与阳性对照片段 $(g f p)$ 一致, 而野生藻 中不存在相应片段, 证明转化成功。

\subsection{GFP 蛋白在集胞藻 6803 中的表达}

野生集胞藻在正常培养条件、高低盐环境中都 不能产生绿色苂光(图 2A)。转化质粒pKW-pro:: $g f p:: k a n^{\mathrm{r}}$ 的转基因集胞藻细胞，在正常培养条件、高 


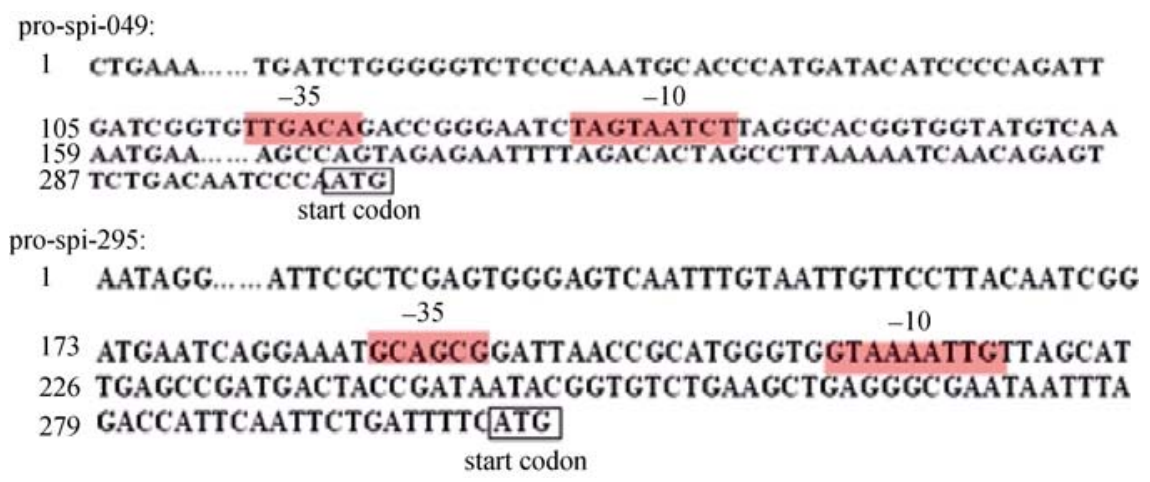

图 1 预测的螺旋藻启动子序列
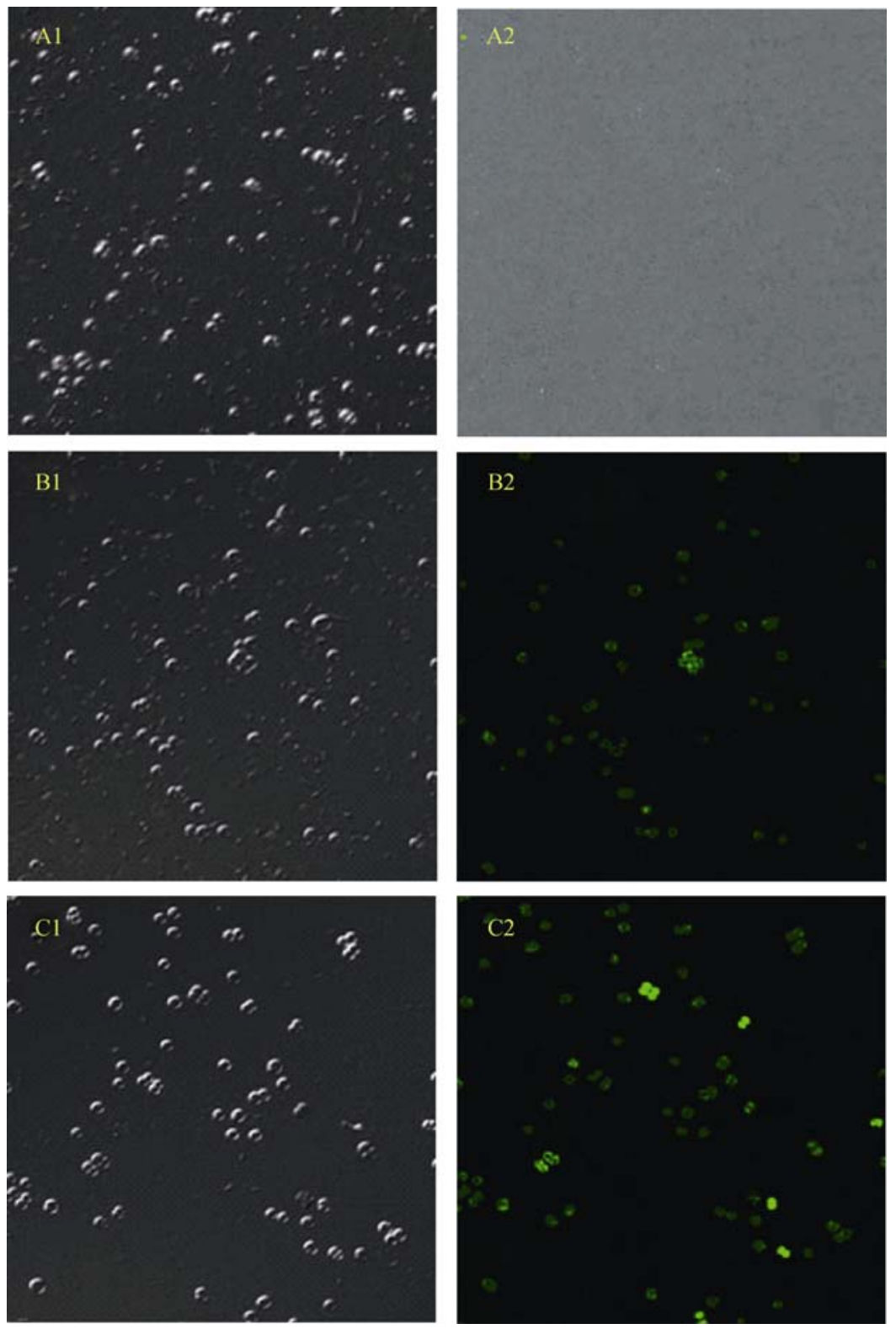

图 2 绿色荧光蛋白在S.PCC6803-pro::gfp:: $\boldsymbol{k a n}^{\mathrm{r}}$ 中的表达

A1、A2: PCC6803; B1、B2: pro-spi-049; C1、C2: pro-spi-295。 
低盐环境中培养后均能检测到绿色苂光。由此可见, 质粒的上、下游集胞藻基因组同源臂与藻细胞染色 体发生同源重组交换，结果使启动子序列、GFP基因 和卡那霉素抗性基因 (pro::gfp::kan ${ }^{\mathrm{r}}$ )整合到染色体 上(S.PCC6803- pro::gfp::kan ${ }^{\mathrm{r}}$ )，启动子启动GFP基因 的转录表达, 使细胞检出绿色苂光(图 $2 \mathrm{~B} 、 \mathrm{C})$ 。经不 同浓度的 $\mathrm{NaCl}$ 刺激一定时间后，经激光共聚焦显微 镜检出, 结果显示含启动子 pro-spi-049 的集胞藻在 $0.4 \mathrm{~mol} / \mathrm{L} \mathrm{NaCl}$ 条件下培养 $6 \mathrm{~h}$ 时苂光表达最强, 含启 动子pro-spi-295 的集胞藻在 $0.6 \mathrm{~mol} / \mathrm{L} \mathrm{NaCl}$ 条件下, 培养 $8 \mathrm{~h}$ 时苂光表达最强, 说明不同螺旋藻基因的启 动子，在不同盐浓度和作用时间下，可诱导受其调 控基因的不同水平的表达(表 2，表 3，图 3)。

表 2 含 049 启动子的集胞藻转化子的诱导结果

盐浓度
$(\mathrm{h})$

注 : 阴性和阳性强弱见图 3。

表 3 含 295 启动子的集胞藻转化子的诱导结果

\begin{tabular}{cccccccc} 
(h) \\
\hline 0
\end{tabular}

注：阴性和阳性强弱见图 3。
通过苂光分光光度计进行苂光定量, 发现含启动子 pro-spi-049、pro-spi-295 的集胞藻的菼光值明显高 于野生集胞藻 $(\mathrm{F}=18.852, P<0.01)$, 说明螺旋藻启动 子在集胞藻中具有启动活性。含启动子 pro-spi-049、 pro-spi-295 的集胞藻的最强单位藻量苂光值分别为 133.60、220.97, 可见启动子 pro-spi-295 的 GFP 表 达较强, 与苂光显微镜下的观察结果基本一致。

\section{3 讨 论}

螺旋藻分布广泛、能够耐受强光、强碱和高盐 等极端条件，其最适钠离子浓度为 $150 \sim 200 \mathrm{mmol} / \mathrm{L}$, 可耐 $1 \mathrm{~mol} / \mathrm{L}$ 的 $\mathrm{NaCl}$ [1,2]。由于螺旋藻可能具备对各 种环境胁迫迅速做出反应的特殊调控机制，研究它 们对高盐胁迫的适应机制，挖掘螺旋藻的耐盐基因 或调控因子，对于构建耐盐性的工业生产用菌和耐 盐、耐渗的植物，改造农作物，来开发利用盐碱地和 增加粮食产量等方面具有广阔的应用前景。

启动子是决定转录起始的顺式调控元件, 通常 位于转录起始位点(TSP)上游的 $-35 \mathrm{bp}$ 和 $-10 \mathrm{bp}$ 处, 被宿主中的RNA聚合酶识别从而启动转录 $[11]$ 。生物 体内基因的表达表现为程序性地开放和程序性地关 闭，而起关键作用的就是启动子。外源基因在宿主 体内表达与否及表达量都直接与启动子有关。我们 应用Online promoter system对螺旋藻的 2 个耐盐基 因的预测启动子序列进行生物信息学分析，表明其 具有类似于TATA-box、CAAT-box 和多个富含 GC 的区域等启动子的特征元件。为进一步明确这些启 动子在耐盐相关基因表达调控中的作用，本实验对 启动子进行了克隆，并利用报告基因技术 ${ }^{[12]}$ 对这些 启动子的转录活性进行了检测, 证实启动子 pro-spi049、pro-spi-295 均具有转录活性, 且可被 $\mathrm{NaCl}$ 诱 导。我们以增强型绿色苂光蛋白作为本实验的报告 基因，其检测灵敏度高、对机体毒副作用小，无需任 何辅助因子和底物的参与, 且可准确检测基因表达 量 ${ }^{[13]}$ ，作为报告基因具有其特有的优越性。

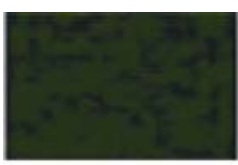

$(-)$

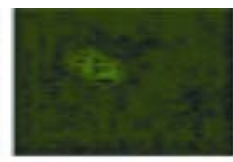

$(+)$

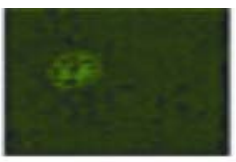

$(++)$

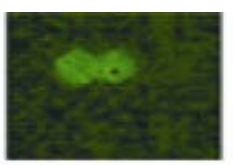

$(+++)$

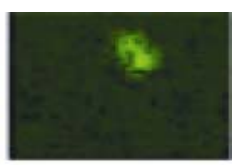

$(++++)$

图 3 激光共聚焦显微镜下荧光亮度标准图 


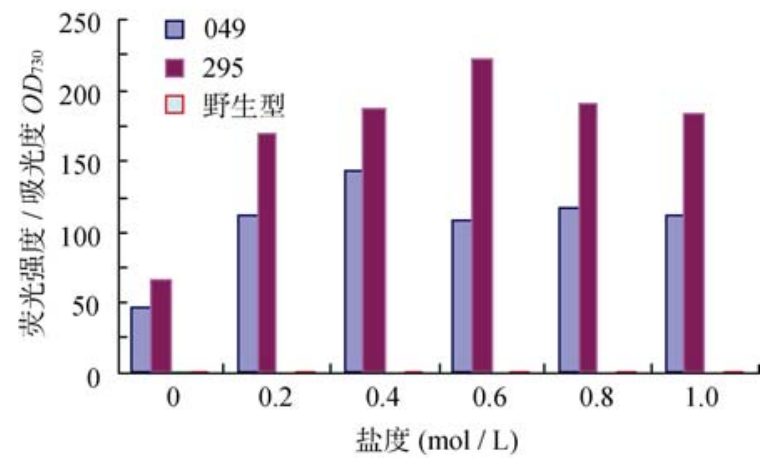

图 4 在不同盐度下, 将重组藻-049 和重组藻-295 分别诱 导表达 $6 \mathrm{~h}$ 和 $8 \mathrm{~h}$ 后的荧光检测

本研究选集胞藻 6803 基因组 $\operatorname{slr} 0168$ 基因及其 上下游相连的两个片段分别作为上游整合平台 (up) 和下游整合平台(down), 在中间插入启动子、 $g f p$ 报 告基因、卡那霉素抗性篮选标记，构建得到同源重 组双交换整合平台，为探索外源蛋白在集胞藻 6803 中表达、高效启动子的篮选等研究提供了很好的转 化、表达、筛选及检测平台, 为进一步探讨螺旋藻 耐盐基因表达调控和相关信号转导机制提供了一个 便捷、灵敏的工具。在下一阶段的研究中我们拟把 报告基因 $g f p$ 更换成耐盐相关基因，转化集胞藻 6803 使其高效表达外源蛋白，验证这些基因在抗逆 过程中的作用，为植物基因工程育种提供新的功能 基因, 也为培育抗逆性增强的螺旋藻新品种、挖掘 其他藻类抗逆功能相关基因奠定基础。

\section{参考文献(References):}

[1] Thomas DJ, Sullivan SL, Price AL, Zimmerman SM. Common freshwater cyan bacteria grow in $100 \% \mathrm{CO}_{2}$. Astrobiology, 2005, 5(1): 66-74.DOI

[2] Ayachi S, El Abed A, Dhifi W, Marzouk B. Chlorophylls, proteins and fatty acids amounts of arthrospira platensis growing under saline conditions. Pak J Biol Sci, 2007, 10(14): 2286-2291. DOI

[3] Wiangnon K, Raksajit W, Incharoensakdi A. Presence of a $\mathrm{Na}^{+}$-stimulated P-type ATPase in the plasma membrane of the alkaliphilic halotolerant cyanobacterium Aphanothece halophytica. FEMS Microbiol Lett, 2007, 270(1): 139-145. DOI

[4] 方孝东, 林栖 凤, 李冠一, 屈良鹄. 盐藻线粒体 GIY-YIG族归巢内切酶基因受到盐胁迫时增强转录. 中 国生物化学与分子生物学报, 2003, 10(5): 625-629. DOI

[5] Fisher M, Gokhman I, Pick U, Zamir A. A structurally novel transferring-like protein accumulates in the plasma membrane of the unicellular green alga Dunaliella salina grown in high salinities. J Biol Chem, 1997, 272(3): 1565-1570. DOI

[6] Fisher M, Zamir A, Pick U. Iron uptake by the halotolerant alga Dunaliella is mediated by a plasma membrane transferrin. J Biol Chem, 1998, 273(28): 17553-17558. $\underline{\mathrm{DOI}}$

[7] Http://www.kazusa.or.jp/cyanobase/synechocystis/index.h tml. DOI

[8] 毛云翔, 张宝红, 杨官品, 张学成. 节旋藻 (螺旋藻) 高分子量DNA的两种制备方法. 海洋科学, 2003, 27(2): 32-36. DOI

[9] 徐旭东, 王业勤, 黎尚豪. 鱼腥藻-大肠杆菌启动子 CAT探测载体的构建. 中国科学院研究生院学报, 1993, 10(2): 203-209. DOI

[10] 迪芬巴赫 CW, 德维克斯勒 GS. PCR实验技术指南. 黄培堂, 俞炜源, 陈添弥, 等译. 北京: 科学出版社, 1998: 380-415. DOI

[11] McClure WR. Mechanism and control of transcription initiation in Prokaryotes. Ann Rev Biochem, 1985, 54: 171204. DOI

[12] Williams JGK. Construction of specific mutations in photosystem II photosynthetic reaction center by genetic engineering methods in Synechocystis 6803. Methods Enzymol, 1988, 167: 766-778. DOI

[13] Hautefort I, Proença MJ, Hinton JCD. Single-copy green fluorescent protein gene fusions allow accurate measurement of Salmonella gene expression in vitro and during infection of mammalian cells. Appl Environ Microbiol, 2003, 69(12): 7480-7491. DOI 